\title{
AMENDMENTS
}

\section{Author Correction: Modeling COVID-19 scenarios for the United States}

IHME COVID-19 Forecasting Team*

Correction to: Nature Medicine https://doi.org/10.1038/s41591-020-1132-9, published online 23 October 2020.

In the Supplementary Information (item 4.4.1, Data processing) of the version of this article initially published, the date range of data incorporated in the reported analyses (23 April 2020 to 26 June 2020) was incorrect. The correct date range is 23 April 2020 to 21 September 2020, as indicated in the main text of the manuscript. The paper and its conclusions are unaffected by this correction to the Supplementary Information. The Supplementary Information has been replaced online with an updated version.

${ }^{*} \mathrm{~A}$ list of authors and their affiliations appears online.

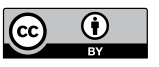

Open Access This article is licensed under a Creative Commons Attribution 4.0 International License, which permits use, sharing, adaptation, distribution and reproduction in any medium or format, as long as you give appropriate credit to the original author(s) and the source, provide a link to the Creative Commons license, and indicate if changes were made. The images or other third party material in this article are included in the article's Creative Commons license, unless indicated otherwise in a credit line to the material. If material is not included in the article's Creative Commons license and your intended use is not permitted by statutory regulation or exceeds the permitted use, you will need to obtain permission directly from the copyright holder. To view a copy of this license, visit http://creativecommons.org/ licenses/by/4.0/.

Published online: 27 November 2020

https://doi.org/10.1038/s41591-020-01181-W

() The Author(s) 2020

\section{Author Correction: Uncovering hidden antimicrobial resistance patterns within the hospital microbiome}

Bastiaan W. Haak (D) and W. Joost Wiersinga

Correction to: Nature Medicine https://doi.org/10.1038/s41591-020-0919-z, published online 8 June 2020.

In the version of this article initially published, the arrow adjacent to 'Biofilm-associated bacteria' in Fig. 1 was upside-down. The correct direction for the arrow is pointing up. The error has been corrected in the HTML and PDF versions of the article.

Published online: 27 November 2020

https://doi.org/10.1038/s41591-020-01184-7

(C) Springer Nature America, Inc. 2020 